\title{
Rejuvenate Groundwater Quality By Artificial Recharge Using GIS And Remote Sensing
}

\author{
Geetha Selvarani Arumaikkani \& Samson Sisupalan
}

\begin{abstract}
Groundwater is an essential and vital natural resource and its significantly use for drinking, irrigation and industrial purposes. But, now-a-days the quality of groundwater is deteriorating day by day due to anthropogenic activities. So we are in a position to assess the quality of groundwater before consumption. The water samples were collected at random locations and it covers all the plain area of the district. The base map of the study area was developed by the Survey of India (SOI) Toposheets and sample locations were marked on that map. The geology, geomorphology, soil, drainage, landuse/land cover, rainfall, water level and rainfall maps of the study area have been digitized using GIS. Water samples were collected from 62 locations and evaluated based on IS:10500-1991 for drinking purpose and suitability of water for irrigation is evaluated by irrigation quality guide lines. Based on the comparison of groundwater quality, Premonsoon groundwater quality is found better than the postmonsoon groundwater quality. It has been discussed that the reason for groundwater quality variation is primarily due to dissolution in groundwater by rainfall infiltrations. It is recognized that the most appropriate method which is readily available now for improvement of groundwater quality through dissolution of artificial recharge. Hence, an attempt is proposed in this work is to improve the groundwater quality by the process of dissolution using artificial recharge by integrating all the thematic map with groundwater quality map in GIS platform. Based on the result it was found that most of the area is covered by moderate to good categories under non natural recharge sites, out of 42 sites, 33 sites falls under this category and it is possible to construct recharge structures and final results are validated with the help of model generated.
\end{abstract}

Keywords-Groundwater, GIS, Artificial Recharge, Water Quality, MATLAB

\section{Introduction}

Groundwater has been a vital natural resource due to its significant use for drinking, irrigation and industrial purposes. Groundwater has been a big variant in quality and quantity with respect to time and space. The groundwater exploitation has reached a stage known as mining exceeding alarmingly the safe yield of the aquifers. It may not be Impertinent to mention that the open wells in the urban areas have all dried up and the people have gone for deep borewells [2]. The quality of groundwater varies mostly with respect to the depth of its availability and it is more so

\section{GEETHA SELVARANI ARUMAIKKANI 1}

SAMSON SISUPALAN 2

Professor, Department of Civil Engineering,

Vel Tech Rangarajan DR.Sangunthala R\& D Institute of Science and Technology,

Avadi, Chennai, Tamil Nadu, India

Mobile: 9003723221

Orcid Id: 0000-0001-5779-6765 in the vicinity of sea due to sea water intrusion. Even within the inland the water quality gets diluted in the monsoon period and gets aggravated in the premonsoon period. Almost $80 \%$ of the groundwater has been used in whole of Tamil Nadu and in around Noyyal river is no exception to this depletion, since it is an agricultural and industrial based area. So the quality of groundwater is deterioting day by day due to over exploitation of groundwater and improper methods of solid waste disposal and untreated effluents into the water bodies[1]. So the available groundwater cannot be used for the above purposes. The aim of the paper is to know the quality of groundwater and also appropriate method which is readily available now for improvement of groundwater quality has been assessed in the study area.

\section{Study Area}

Noyyal river is one of the tributaries of the river Cauvery, which originates from the hills of Vellingiri, also termed as southern Kailayam in Western ghats and flows towards the southwest of Coimbatore district in Tamil Nadu, and finally it ends in river Cauvery at Kodumudi in Karur district. It flows through Coimbatore, Tiruppur, Erode and Karur districts with its catchments in seven taluks (Coimbatore, Tiruppur, Avinashi, Palladam, Dharapuram, Erode and Karur). It flows over a length of about $180 \mathrm{Km}$ covering an area of $3510 \mathrm{~km}^{2}$. Out of the total area in the basin, $1752 \mathrm{~km}^{2}(49.9 \%)$ of the area is under cultivation and $178 \mathrm{~km}^{2}(5.1 \%)$ is covered by forest and wetland growing teak and eucalyptus and the rest $1580 \mathrm{~km}^{2}(45 \%)$ is barren land (Senthilnathan 2001). The boundary of the river basin is between north latitude $10^{\circ} 54^{\prime}, 00^{\prime \prime}$ to $11^{\circ} 19^{\prime} 03^{\prime \prime}$ and east longititude $76^{\circ} 39^{\prime} 30^{\prime \prime}$ to $77^{\circ} 55^{\prime} 25$ " which is shown in Figure 1. More than 100 villages are situated on both sides of the banks of river Noyyal.

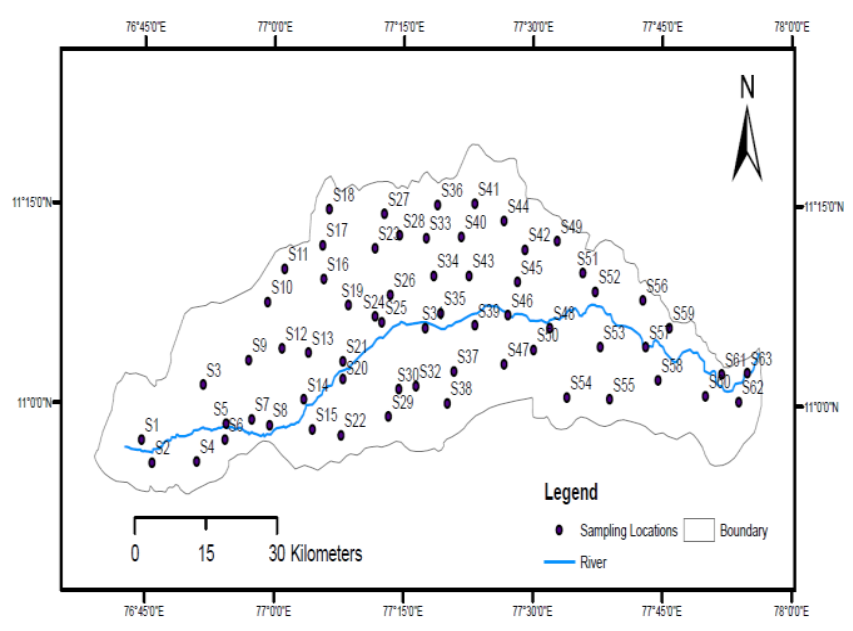

Figure 1 Key Plan Showing the Study Area Details and sampling stations 
Noyyal river is a major source for irrigation, drinking and other activities of the people living on both sides of the river and even for the people living beyond 3 $\mathrm{kms}$ from the river. The average rainfall in the basin is about $700 \mathrm{~mm}$. The river flows from west to east and its maximum elevation is around $1600 \mathrm{~m}$ above mean sea level and the minimum elevation is $100 \mathrm{~m}$ above mean sea level (Sankaraaj et al 2002). It is also believed that water contains natural medicine and therefore it is good for health. The Noyyal is a seasonal river which has good flow only for short period during the northeast and southwest monsoons. Occasionally flash floods occur when there is heavy rain in the catchment areas. Apart from these period, there is only scanty flow in most part of the year. Floods are common during the rainy season due to the steep slopes in the upper part of the catchments (Sankaraaj et al 2002). Nearly 6,000 acres of cultivable land in Coimbatore district is irrigated by using river water (Appasamy and Prakash Nelliyat 2007).

Groundwater status in the entire Noyyal basin is highly varying in the absence of good rainfall over the past few decades and the available groundwater has got highly depleted due to over exploitation. The groundwater recharge in Noyyal basin is due to monsoon and non monsoon rains, rainfall seepage due to wet cultivation, seepage from water bodies such as tanks, anaicuts, canals and reservoirs. Water available for recharging the groundwater has become very low in some areas. Past records shows that the depth of water levels in ayacut lands on an average varied between 3 $\mathrm{m}$ to $20 \mathrm{~m}$ below ground level (bgl). In non- ayacut areas, depth of the well varies from 27 to $42 \mathrm{~m}$ bgl. Currently the water depth in non ayacut areas has reached even up to 165 $\mathrm{m}$ bgl. The groundwater table considerably goes down due to indiscriminately sinking deep bore wells and poor recharge due to scanty rain and absence of many surface water bodies.

Coimbatore has attached a number of large industries like textile mills, textile machinery, cement, rubber transport equipment etc. Currently there are 37,000 registered and 10,000 unregistered small scale units are functioning in and around Coimbatore. At present 6355 industries are in Tiruppur and 11300 industries are in Erode districts. These industries dump their wastes near the water bodies that are assumed as dumping yards, which affects the groundwater quality in the river basin.

\section{Methodology}

To assess the present status of groundwater quality, sixty three groundwater samples were collected from four districts during the months of January 2007 and June 2007 and were plotted on base map. The water samples were analysed for various physico chemical parameters like $\mathrm{pH}$, total dissolved solids, chlorides, calcium, nitrate, hardness, iron, sulphate, fluoride and alkalinity by adopting IS procedure[4,5,6]. Using overlaying and integration analyses were done to identify suitable sites of groundwater quality for domestic purposes[7] and also rejuvenating technique was identified to increase quality of groundwater .

\section{Result and Discussion}

Using ArcGIS 8.2, overlaying was done by adding the weights of the classified themes of hardness, TDS,

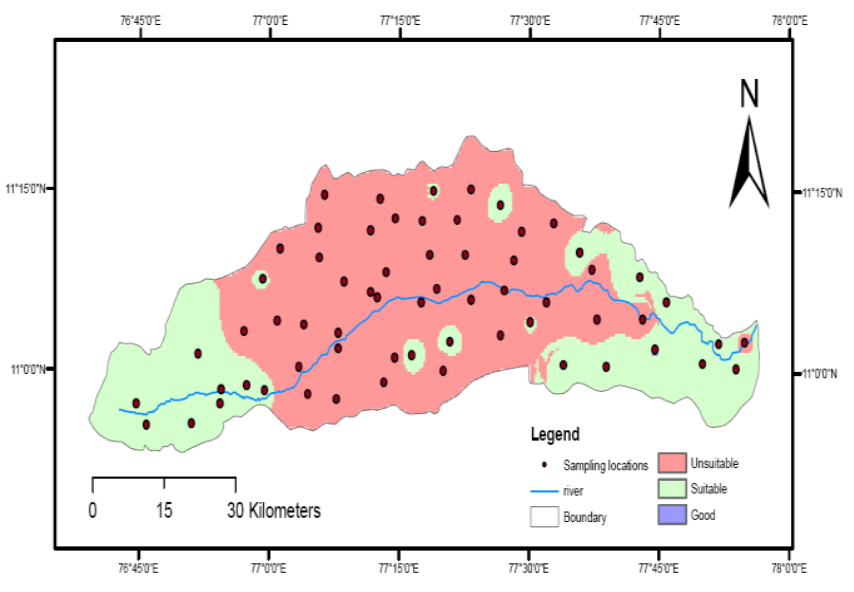

Figure 2 Spatial Distribution of Groundwater Quality for Drinking in Postmonsoon

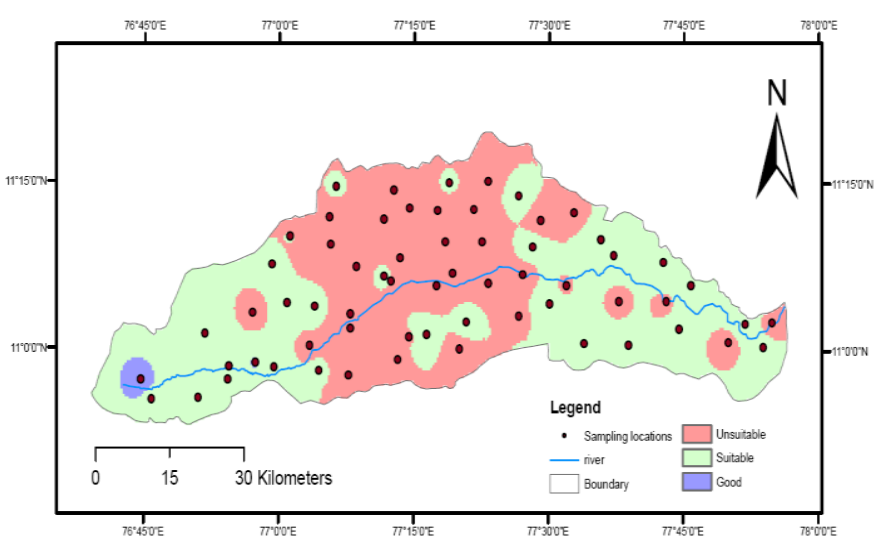

Fig. 3Spatial Distribution of Groundwater Quality for Drinking in Premonsoon

alkalinity, chlorides and calcium were used to prepare a map of groundwater quality suitable for domestic purpose. This analysis has categorized the study area into three zones (good, moderate and poor). The spatial variation of suitable zones for domestic purposes based on groundwater quality for both postmonsoon and premonsoon are shown in Figures 2 and 3.

Fig. 2 and Fig. 3 reveals that the groundwater quality was fairly good and it was suitable for drinking in the upper reaches of the river Noyyal, before the Coimbatore city. But after Coimbatore the water quality was very poor and it was unsuitable for drinking purpose. GIS analysis, reveals that the quality of groundwater was predominantly poor cat egory in both premonsoon and postmonsoon, while the good category water was found in Thondamuthur block during premonsoon period. The suitable quality was found in southwestern, western and southeastern side of the river basin. The discharging of industrial and domestic effluent on either side of the river was ultimately polluting the groundwater of the study area and this reflects in the downstream of Tiruppur during premonsoon period the potable ground water was found in larger area than during the postmonsoon period.

Using Arcview 3.2a overlaying was done by adding the weights of the classified themes of both postmonsoon and premonsoon and was used to prepare a map of groundwater quality suitable for domestic purpose of the study area. This analysis has categorized the study area into 


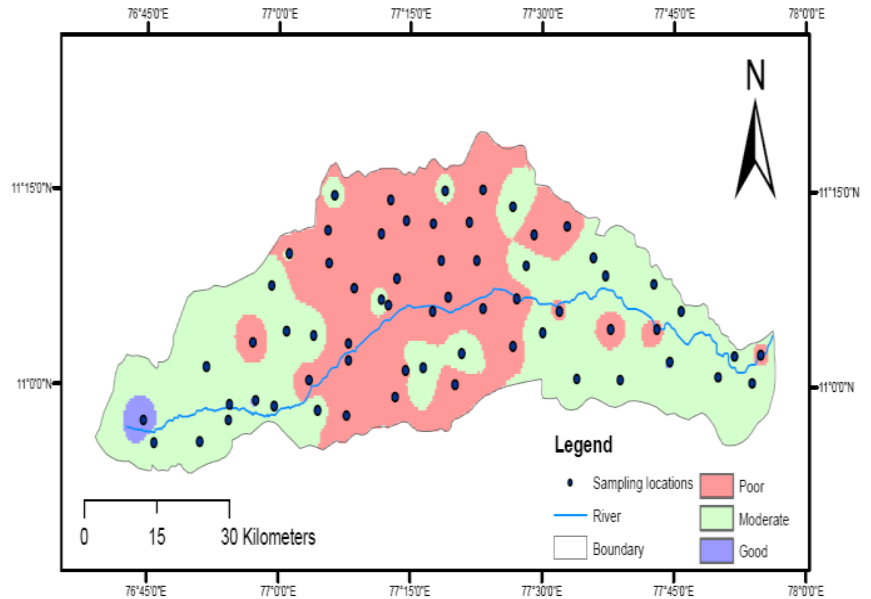

Fig. 4 Spatial Distribution of Groundwater Quality Showing Suitable Zone for Drinking in Premonsoon and Postmonsoon

three zones (good, moderate and poor). The spatial variation of suitable zones for domestic purpose based on groundwater quality is shown in Figure 4

Suitability of groundwater for drinking purpose based on the thematic map for both the seasons reveals that groundwater quality was found under moderate category in south western, eastern and north eastern side of the study area, while good category water was found in Thondamuthur block in south eastern side of the study area. Poor category was found in southern, centre and northern parts of the study area. The highly polluted blocks were Annur, Avinashi, Tiruppur, Sulur, Sultanpet, Palladam, Pongalaur, Uthukuli and few isolated parts of Kangeyam and Perundurai blocks.

The artificial recharge sites was identified by integrating available maps like geology, geomorphology, slope, drainage density, lineaments density, rainfall, water level and land use/land cover map by using weighted overlay analysis.

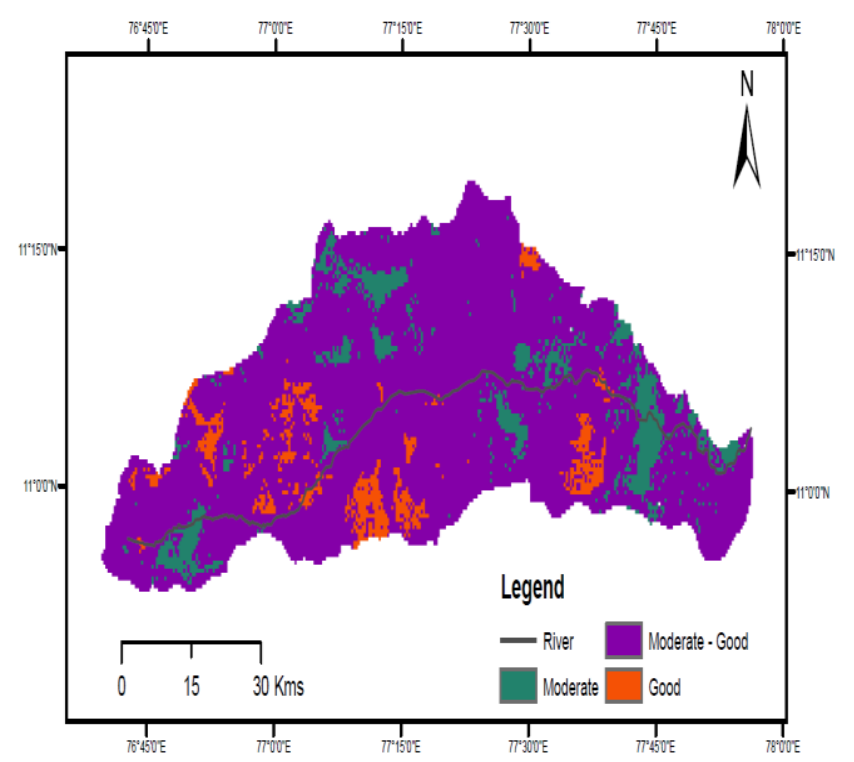

Fig. 5 Artificial Recharge Sites Map
Based on Fig. 5, artificial recharge sites were predominant in moderate to good category (occupies $83.52 \%$ of the study area) due to the presence of pediments and gneiss, red calcareous and thin red soil with high lineament density. Artificial recharge was found under good category (occupies $6.12 \%$ of the study area) in few patches of south western side and western side of the study area due to the presence of red calcareous, flood plain, pediment, shallow pediment and deep pediment, valley fill, unclassified gneiss, charnockite, complex gneiss and fallow land. The artificial recharge was found under moderate category (occupies $10.36 \%$ of the study area) in western, south eastern and north eastern side of the study area due to the presence of red calcareous, black soil, colluvial and alluvial soil, shallow buried pediment, shallow pediment, pediment, charnockite, complex and unclassified gneiss.

\section{v. Conclusion}

Based on the comparison of groundwater quality, Premonsoon groundwater quality is found better than the postmonsoon groundwater quality. It has been discussed that the reason for groundwater quality variation is primarily due to dissolution in groundwater by rainfall infiltrations. It is recognized that the most appropriate method which is readily available now for improvement of groundwater quality through dissolution of artificial recharge. Hence, an attempt is proposed in this work is to improve the groundwater quality by the process of dissolution using artificial recharge by integrating all the thematic map with groundwater quality map in GIS platform. Based on the result it was found that most of the area is covered by moderate to good categories under non natural recharge sites, out of 42 sites, 33 sites falls under this category and it is possible to construct recharge structures and final results are validated with the help of model generated by simulink.

\section{References}

[1] Sankaraaj L., Subramanian T.P., Siddhamalai A., and Farooque Ahmed N. 'Quality Of Soil And Water For Agriculture In Noyyal River Basin',Tamil Nadu', Joint Director of Agriculture (Research), Soil Survey and Land Use Organization, Tamil Nadu Department of Agriculture, Coimbatore, pp.2-4.,2002,.

[2] S.Venkateswaran, and Deepa, S. "Assessment of Groundwater Quality using GIS Techniques in Vaniyar Watershed, Ponnaiyar River, Tamil Nadu'. ICWRCOE'15, vol.4, pp.1283 to 1290, 2013.

[3] S Venkateswaran,., M., Elangomannan, and M., Vijay Prabhu, "Evaluation of Physico-Chemical Characteristics in Groundwater Using GIS - A case Study of Chinnar Sub-basin of Cauvery River, Tamil Nadu, India”. Ultra Scientist Vol. 24 (3) B, 387-398, 2012.

[4] WHO) Guidelines for drinking water quality (3rd ed.).Geneva, pp 540,2008 .

[5] IS 10500-1991.,1991, 'Indian Standard Drinking Water Specification', Bureau Of Indian Standards, New Delhi,.2-4.

[6] APHA., Standard Methods For The Examination Of Water And Waste Water, 19th edn., American Public Health Association, Washington, DC, 1995

[7] G.D Agarwal., S.K Lunkad., and T Malkhed., 'Diffuse Agricultural Nitrate Pollution Of Groundwater In India', Water Science and Technology, Vol.39(3), 67-75, 1999. 
Proc. of the Eighth International Conference On Advances in Applied Science and Environmental Engineering - ASEE 2018 Copyright (C) Institute of Research Engineers and Doctors. All rights reserved.

ISBN: 978-1-63248-143-6 doi: 10.15224/ 978-1-63248-143-6- 02

About Author (s):

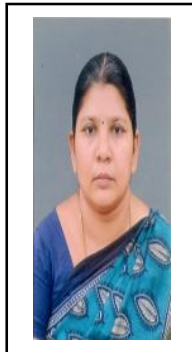

Geetha Selvarani. A has completed her Ph.D at the age of 31 years from Anna University, Chennai. She has published more than 35 papers in reputed journals and conferences and has been serving as an editorial board member and reviewer for various reputed journals. She has published five books are having with ISBN No and filed two patterns. She was participated as Invited speaker and chair person for the 5th International Conference on Civil Engineering and Urban Planning (CEUP2016) held in Xian, China from 23rd to 26th,August.She is a member in Technical Program Committee for " International Conference on Geomatics and Civil Engineering [GCE2017]", September 8th - 10th, 2017, Shanghai, China.
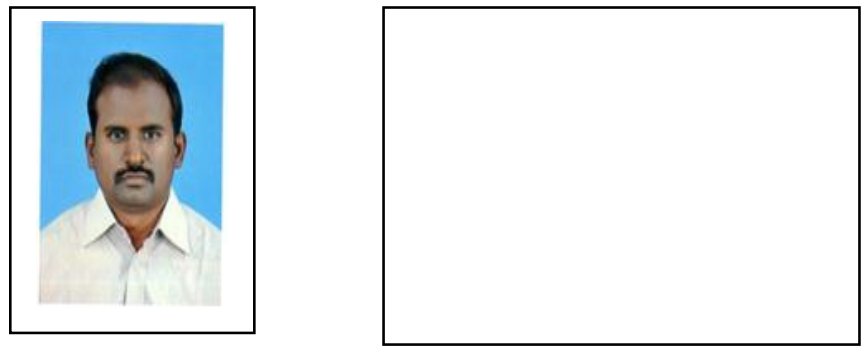